\title{
Developing VAT treaties: international tax cooperation in times of global recovery
}

\author{
Yige $\mathrm{Zu}^{*}$ (1D) \\ Durham Law School, Durham University, Durham, UK \\ ${ }^{*}$ Author email: yige.zu@durham.ac.uk
}

(Accepted 5 June 2021)

\begin{abstract}
The Covid-19 pandemic highlights the pressing need to address common challenges faced by all countries and, in particular, provide special support to developing countries through international cooperation. Taxation, in particular Value Added Tax (VAT), is a key area for strengthening international cooperation because of its critical role in financing the Covid-19 crisis and supporting global recovery. This paper proposes the adoption of VAT treaties based on two considerations. First, there exist, in the interplay between states' VAT laws, over-taxation and under-taxation that can be more effectively addressed by treaties than by unilateral state actions. Secondly, unlike income tax treaties, VAT treaties would distribute more benefits from cooperation to developing countries than to developed countries, leading to normatively attractive distributional consequences. The proposed model offers a new approach to taxing cross-border transactions under VAT and could form part of a coordinated response to a sustainable post-pandemic recovery.
\end{abstract}

Keywords: international tax; value added tax; Covid recovery; tax treaties; international cooperation

\section{Introduction}

The outbreak of Covid-19 has resulted in simultaneous public health, social and economic crises in almost all countries. As governments around the globe navigate through the crises, tax policy has been used as a critical instrument in immediate government responses to provide support to households and keep businesses afloat. ${ }^{1}$ It is unquestionable that the tax system will play an important role in paying off the soaring national debts, financing Sustainable Development Goals and fostering global recovery in the aftermath of Covid-19 once containment of the health crisis is in sight. Whilst the pandemic presents a global challenge, international tax cooperation needs to be strengthened more than ever to develop effective and coordinated responses and address the intensified revenue needs faced by all countries, in particular developing countries that have been disproportionately affected by the pandemic and yet have a much lower tax-to-GDP ratio. ${ }^{2}$

For over a century, international tax cooperation has primarily been achieved in the field of income tax through a network of bilateral treaties that resolve double taxation and non-taxation resulting from overlapping and conflicting jurisdictional claims. The extensive income tax treaty network now consists of over 3,000 bilateral treaties. In another key area of fiscal law, VAT, however, international

\footnotetext{
${ }^{1}$ See eg R Krever 'Tax responses to a pandemic: an Australian case study' (2020) 1 Belt and Road Initiative Tax Journal 52.

${ }^{2}$ The average tax-to-GDP ratio in developing countries included in the OECD Revenue Statistics database is almost half of the OECD average. See OECD 'Domestic revenue mobilisation: a new database on tax levels and structures in 80 countries' (2018).

(c) The Author(s), 2021. Published by Cambridge University Press on behalf of The Society of Legal Scholars. This is an Open Access article, distributed under the terms of the Creative Commons Attribution-NonCommercial-NoDerivatives licence (https://creativecommons.org/ licenses/by-nc-nd/4.0/), which permits non-commercial re-use, distribution, and reproduction in any medium, provided the original work is unaltered and is properly cited. The written permission of Cambridge University Press must be obtained for commercial re-use or in order to create a derivative work.
} 
agreements are nearly absent. This raises an important question that has rarely been asked: should cooperation by way of treaties be pursued in VAT? ${ }^{3}$

As the main general consumption tax in about 170 countries, ${ }^{4}$ VAT is a key source of revenue for Organisation for Economic Co-operation and Development (OECD) countries and has even greater significance in terms of revenue yields in middle- and low-income countries. Despite the geographical and revenue significance of the tax, almost all countries face significant challenges in taxing crossborder transactions in the digital economy, where over-taxation and under-taxation might arise in the absence of international coordinated actions. Addressing the common challenges in this area through international cooperation will become more pressing in a post-pandemic world. While traditional trade suffers massive disruptions to business and supply chains due to the unprecedented restrictions on the physical movement of goods and people, the pandemic has accelerated the shift to digital trade and e-commerce. The ongoing disruptions to the global economy call for rapid actions by international organisations and governments to support businesses to operate globally in a digital world. International VAT rules must be developed, in conjunction with policy in other fields, to meet the demands of the new digitalised trade environment.

This paper argues the case for the adoption of VAT treaties based on a common model, drawing on the experience of bilateral income tax treaties, as part of coordinated actions to aid global recovery. The case for VAT treaties is built on two main considerations. The first is the need for cooperation. There exist, in the interplay between states' VAT laws, over-taxation and under-taxation that can be more effectively addressed by treaties than by unilateral state actions. The paper also examines how the current income tax treaties would provide an attractive role model for designers of VAT treaties to follow. The jurisdictional issues in income tax and VAT have both similarities and differences. Where there is a match between the underlying problems, the income tax model can be directly applied to solve the VAT problems. Where the underlying problems differ, the paper shows how income tax treaty measures could provide sufficient remedies to the different VAT problems.

The need for cooperation alone is not sufficient to justify the desirability of treaties because cooperation inevitably comes with costs. The second factor considered in this paper is that international cooperation by way of VAT treaties would produce distributionally desirable consequences, delivering more benefits to developing countries than to developed countries. The desirability of income tax treaties has been called into question because of their unfair distributional consequences, with the benefits of cooperation flowing from developing to developed countries. The desirable distributional consequences of the proposed VAT treaty provide a further compelling case for the adoption of VAT treaties. In particular, the desirable distributional consequences secured in the VAT treaties would to some extent temper the unfair distribution in the income tax treaties and therefore improve the overall fairness of international tax cooperation.

The paper suggests that in the case that treaty provisions are not distributionally neutral, bilateral treaties can be more easily achieved than a multilateral treaty. A common model treaty needs to be developed to reduce transaction costs involved in bilateral negotiations. The VAT treaties would therefore take the form of bilateral treaties based on a common model. They could be incorporated into the existing bilateral income tax treaties to increase the bargaining potential of developing countries.

The proposed model offers a new approach to taxing cross-border transactions under VAT and can be used by policymakers as a basis for developing a collective and coordinated response to postpandemic recovery. Closing the VAT gap in the context of cross-border transactions would not only secure additional revenue needed to cover the costs of Covid-19 and support economic resilience in the short term, but also contribute to long-term tax capacity building in all countries involved. The model would also ease over-taxation and reduce tax obstacles to international trade to stimulate cross-

\footnotetext{
${ }^{3}$ The question was posed in NP Eriksen 'Should tax treaties play a role for consumption taxes?' (2005) 33 Intertax 166. Ecker proposed a VAT model treaty in T Ecker A VAT/GST Model Convention (IBFD, 2013). This model, however, may not be achievable for the reason explained in the text at $\mathrm{n} 56$.

${ }^{4}$ The US is the only developed country that does not have a VAT.
} 
border activities in times of economic downturn. In addition to addressing the common challenges faced by individual countries, the desirable distributional consequences of the model would help narrow the global inequality exposed and exacerbated by the pandemic.

\section{VAT}

\section{(a) A neutral tax on international trade}

Developed independently in the 1920s by an American academic and German industrialist, the idea of a VAT lay dormant until resurrected in continental Europe a few years after the end of World War II in the post-war reconstruction period when the many European economies were faltering. At the time, an important source of revenue for almost all Western European countries, apart from the UK, was a 'turnover' tax imposed on business sales. The UK applied a 'purchase tax', first enacted during World War II. ${ }^{5}$ Because the turnover taxes applied to all sales, the burden compounded along business supply chains, yielding two significant economic harms: first, the compounding tax encouraged vertical integration by businesses, leading to large and very often inefficient conglomerates as businesses tried to fill every need internally; secondly, the compounding tax had a significant negative impact on the price of sales abroad, making exports uncompetitive.

France was the first European country to attempt a solution to the cascading and cross-border sale problems with the adoption in 1948 of a limited 'credit' mechanism for a narrow turnover tax. Businesses eligible for the relief continued to pay turnover tax on all sales but were able to recover some 'input tax' included in the cost of acquisitions. The input tax credit system was extended to the general turnover tax regime in 1954 to establish what became the predecessor to the VAT system.

The distortion of the turnover taxes with respect to cross-border sales was considered a serious obstacle to the completion of the internal market in the European Economic Community (EEC), as the European grouping was known at the time, which requires that supplies made locally and imported from another member state are taxed on the same basis. It was in this environment that the EEC Commission, exercising authority granted under the Treaty of Rome creating the EEC, ${ }^{6}$ established a Fiscal and Financial Committee charged with developing recommendations for a Community-wide solution to the inefficiency of the turnover taxes levied by member states and removing any tax constraints on cross-border sales within the Community. Chaired by German economist Fritz Neumark, the Committee issued a report in 1962 that subsequently became known as the Neumark Report, explaining how a comprehensive VAT could address both problems. ${ }^{7}$

The proposed tax would remove the cascading taxation of turnover taxes by rebating, through a credit mechanism, all turnover tax included in the price of acquisitions by registered businesses. A fundamental principle of VAT is that it is a tax on final consumption, with the tax burden falling on final consumers only. In cross-border sales, this is achieved by applying the destination principle: the tax would operate as a 'destination basis' tax that 'zero rate' exports, meaning no tax would be imposed on exported goods or services and exporters would recover all tax on inputs, leaving the export free of taxation in the country of origin; imports would be subject to tax in the same manner as locally produced supplies, yielding complete neutrality between imports and local production.

Soon after the release of the Neumark Report, the EEC Council issued two Directives in 1967 mandating the adoption of VAT systems in all member states and setting out the common rules on the place of taxation for cross-border supplies. ${ }^{8}$ As a result, all member states had VATs in place but

\footnotetext{
${ }^{5}$ For details of the purchase tax see The Exchequer Report of the Committee on Turnover Taxation (Cmnd 2300, 1964).

${ }^{6}$ Treaty establishing the European Economic Community, Art 99.

${ }^{7}$ EEC Commissioner Report of the Fiscal and Financial Committee on Tax Harmonization in the Common Market (Neumark Report), Report 21, Doc SD-32, EEC Commission, 1962; an unofficial English translation by Dr H Thurston was published by the International Bureau and Fiscal Documentation in 1963 under the title 'The EEC Reports on Tax Harmonisation: The Report of The Fiscal and Financial Committee and The Reports of The Sub-Groups A, B and C'.

${ }^{8}$ First Council Directive 67/227/EEC of 11 April 1967 on the harmonisation of legislation of Member States concerning turnover taxes; and Second Council Directive 67/228/EEC of 11 April 1967 on the harmonisation of legislation of
} 
the details of the taxes varied significantly. Genuine harmonisation was only achieved a decade later in 1977 with the adoption of the Sixth Directive on VAT. ${ }^{9}$

The VAT was initially adopted in the EU as the mandatory form of general sales tax because of its advantage in achieving equal treatment of domestic and imported goods with precision through the destination principle. The EU VAT experience was considered an enormous success by other countries, and consequently, VAT quickly spread around the world in the 1980s and 1990s. VAT is now a key type of consumption tax in about 170 countries. Most VAT jurisdictions outside the EU more or less followed the EU model in designing the tax. The world's VAT systems are thus broadly similar compared to income tax, an outcome to a large extent attributed to the harmonisation of VAT in the EU. ${ }^{10}$ The destination principle has become an international norm and is applied in cross-border transactions in almost all VAT jurisdictions.

\section{(b) Jurisdictional overlaps or conflicts}

When VAT applies to international cross-border transactions involving suppliers in one jurisdiction and customers in another, jurisdictional overlaps or conflicts may arise in terms of legislative jurisdiction (the power to make the laws) and enforcement jurisdiction (the power to enforce compliance with legal commands), leading to either over-taxation or under-taxation. A fundamental principle of VAT is that the tax should apply to all types of supplies and it should apply only once so that it is neutral in its application to all consumption. Both over- and under-taxation create economic distortions by favouring some supplies over others.

\section{(i) Overlapping legislative jurisdictions}

Overlapping legislative jurisdictions may arise in two circumstances. First, although the destination principle assigns tax jurisdiction only to the country where consumption takes place, consistent application of the principle across countries requires common understanding of the place of consumption. The place of consumption of tangibles is normally determined on the basis of the location of goods, which can be easily identified with effective border controls. The determination of the place of consumption of intangibles is less straightforward because intangibles do not move across borders and cannot be physically tracked. ${ }^{11}$ It is probable that both the supplier's and the customer's jurisdictions agree that only one jurisdiction, namely the jurisdiction in which the final consumption takes place, has legislative jurisdiction to tax but hold different views on the place of consumption. ${ }^{12}$ When this happens, the final transaction might be subject to tax in both countries if they both regard themselves as the place of consumption. ${ }^{13}$

The provision of entertainment services via the internet provides an example of a supply that raises overlapping jurisdiction issues; the place of consumption may be considered to be where the provider carries on his business, where the customer is located, or where the services are physically performed under VAT laws in different countries. ${ }^{14}$ The same service could be subject to tax claims by three states

Member States concerning turnover taxes- Structure and procedures for application of the common system of value added tax.

${ }^{9}$ Sixth Council Directive 77/388/EEC of 17 May 1977 on the harmonization of the laws of the Member States relating to turnover taxes - common system of value added tax: uniform basis of assessment.

${ }^{10} \mathrm{~V}$ Thuronyi et al Comparative Tax Law (Kluwer Law International, $2^{\text {nd }}$ edn, 2016) p 281.

${ }^{11} \mathrm{M}$ Keen and W Hellerstein 'Interjurisdictional issues in the design of a VAT' (2010) 63 Tax Law Review 359.

${ }^{12} \mathrm{~W}$ Hellerstein 'Jurisdiction to tax income and consumption in the new economy: a theoretical and comparative perspective’ (2003) 38 Georgia Law Review 1.

${ }^{13}$ Omitted from the analysis here is a theoretically possible, but in practice much rarer possibility - namely double nontaxation that arises when neither of the two countries consider themselves as the place of consumption. An example is that international transport of passengers from Australia to New Zealand is zero-rated under both New Zealand and Australian VAT (known as Goods and Services Tax in these countries) Acts.

${ }^{14}$ Hypothetical examples of conflict in cross-border VAT rules can be found in R Millar 'Cross-border services - a survey of the issues' in R Krever and D White (eds) GST in Retrospect and Prospect (Thomson Brookers, 2007). 
if the business provider, the actual services performers and the customers were all located in different jurisdictions that have different views on the place of consumption. ${ }^{15}$

A further conflict of legislative jurisdictions may arise as a result of the indirect nature of VAT and the gaps between domestic rules that have no extraterritorial application in the circumstances where foreign registered businesses incur business expenses in a country. VAT operates as an 'indirect tax' in the sense that the persons who have the legal obligation to remit the tax are different from those who bear the economic burden of the tax. Although VAT is a tax on final consumption, the tax is collected piecemeal from business suppliers along the supply and distribution chain that are expected to pass on the tax burden to the final consumers, rather than from the final consumers directly. The operational mechanism of most VAT systems requires that all taxes borne by the buyer in a business-to-business acquisition should be removed by providing the buyer with a credit to offset the tax paid on acquisitions to be used in the business. This will not be possible if the vendor's country does not accept credit claims by foreign registered enterprises and the buyer's country does not provide credits for VAT paid to foreign suppliers, which is the current state of play in most countries. This type of conflict and the resulting over-taxation are considered a significant barrier to international trade and investment by businesses frequently incurring expenses in other countries. ${ }^{16}$

\section{(ii) Territorial constraints on enforcement jurisdiction}

Even though legislative jurisdiction is entirely territorial, there may be circumstances where extraterritorial enforcement is necessary for the law to be effective. Cross-border supplies by foreign businesses to domestic consumers give rise to enforcement issues easily avoided in a fully domestic transaction. Although the tax is intended to operate as a tax borne by final consumers, it is the supplier only that is required to register and remit the tax. The system works well so long as the supplier is present in the state and easily susceptible to the state's enforcement mechanisms.

The operational model proved problematic in the case of foreign suppliers out of reach of local tax officials, however. Under international law, enforcement of a state's fiscal laws within another state's geographical borders is only allowed with the latter's consent. ${ }^{17}$ To overcome the lack of enforcement jurisdiction over foreign suppliers, VAT systems have variously experimented with alternative enforcement regimes. Initially, most VAT systems responded to the challenges by shifting responsibility for remitting VAT from the supplier to the customer. In the case of intangible supplies, this was done through what became known as a 'reverse charge' rule that required the customer to file a VAT return and declare the tax due on imports. A parallel response was adopted for importation of tangible goods by customers which were often stopped at post offices or courier depots until the intended customers paid VAT due.

The reverse charge system used for imports of intangible supplies worked well when the customer was a local registered enterprise subject to full audit procedures but proved problematic when extended to final consumers in the internet age. ${ }^{18}$ Likewise, the tax before final delivery system used for imports of tangible products fared better prior to the internet age but proved wholly unsustainable with the enormous growth of online orders from foreign suppliers either directly or via retail platforms that overwhelmed the enforcement capacity of modern tax administrations. To cope with the influx of imports ordered online, most jurisdictions adopted exemptions from VAT for low-value imported

\footnotetext{
${ }^{15}$ The possibility was canvassed in Staatssecretaris van Financiën v L W Geelen (Case C-568/17) (8 May 2019), where a Dutch adult services provider used Philippine personnel to provide services to clients in the Netherlands. The CJEU considered the state where the provider carried on his business (the Netherlands) was the place of supply and had the jurisdiction to tax.

${ }^{16}$ OECD 'VAT/GST relief for foreign businesses: the state of play - a business and government survey' (February 2010), available at https://www.oecd.org/tax/consumption/44560750.pdf.

${ }^{17} \mathrm{~F}$ Mann 'The doctrine of jurisdiction in international law' (1964-I) Hague Recueil at 139.

${ }^{18}$ The reverse charge approach is used for inter-provincial imports by final consumers in the Quebec Sales Tax system in Canada. See R Bird and P-P Gendron 'Dual VATs and cross-border trade: two problems, one solution?' (1998) 5 International Tax and Public Finance 429.
} 
goods and digital supplies, a response that recognised the limitations of revenue authorities' administrative capacity. ${ }^{19}$ However, under-taxation of these imports prompted complaints by local retailers of similar goods or services that are subject to full taxation and gave rise to significant revenue loss. ${ }^{20}$ Collection of VAT on imports of digital supplies and low-value goods by final consumers remains an outstanding enforcement difficulty that needs to be resolved urgently, with Covid-19 further shifting the tax base from the traditional bricks-and-mortar economy to the digital economy.

\section{(c) Why are there no VAT treaties?}

The proliferation of income tax treaties matched by the almost universal adoption of VAT across the globe raises an obvious question - why has the global community not witnessed an equal growth of VAT treaties? Previously, VAT treaties were considered unnecessary because the relative uniformity of VAT systems and the single destination principle underlying allocation rules largely reduced the possibilities for jurisdictional conflicts. ${ }^{21}$ This view no longer holds valid when globalisation, deregulation and digital transformation pose challenges to the application of VAT to cross-border sales that require remedies. ${ }^{22}$ Two larger geo-political factors and the growing use of self-help responses to the collisions of legislative and enforcement jurisdictions help explain the dearth of VAT treaties.

\section{(i) Resolution of VAT within the EU by treaty}

In income tax, much of the momentum for the take-up in tax treaties can be traced to the OECD's initiatives and follow-up treaty activities by its members. A majority of its members are also members of the EU, whose predecessor body is largely responsible for the growth of VAT. The overlap of membership in the EU and the OECD helps explain why there has been no impetus for a majority of OECD members to push for treaty solutions as there was for income tax.

To the extent that income tax treaties are perceived as a means of achieving greater harmonisation of diverse national income tax systems, ${ }^{23}$ the EU VAT Directive governing the most important substance of all EU VAT laws acts as a quasi-multilateral 'VAT treaty', harmonising 28 national VAT systems (before the UK's exit from the EU). The principal directive ${ }^{24}$ achieves uniform place of taxation rules across the member states and supplementary and complementary directives ${ }^{25}$ provide comprehensive solutions to the collection of VAT on cross-border sales and the refund of VAT on expenditures incurred by businesses registered in another state.

Although member states were in theory part of a single economic community, until 1993 border controls remained between states, enabling both exporting and importing countries to track the movement of goods. It was, consequently, not difficult to refund input tax in the exporting country and assess tax in the importing country in the case of intra-Community sales of goods. With the abolition of fiscal borders, new mechanisms were needed to ensure VAT was levied on a destination basis and exporters were able to recover all input tax. A variety of systems evolved over the following two and a half decades to accommodate changes in the European economy, most recently the rise of sales over internet platforms and the provision of digital services. The current rules provide separate regimes for

\footnotetext{
${ }^{19}$ An example is the Low Value Consignment Relief in the EU that exempted from VAT imports of goods valued at $€ 22$ or less before 1 January 2021.

${ }^{20}$ Commission 'Modernising VAT for e-commerce: question and answer' MEMO/16/3746; Productivity Commission, Australian Government Collection Models for GST on Low Value Imported Goods: Productivity Commission Inquiry Report (Commonwealth of Australia, 2017).

${ }^{21} \mathrm{BJ}$ Arnold et al 'Summary of the proceedings of an invitational seminar on tax treaties in the $21^{\text {st }}$ century' (2002) 50 Canadian Tax Journal 65.

${ }^{22}$ OECD 'The application of consumption taxes to the trade in international services and intangibles' (2004).

${ }^{23}$ Arnold et al, above n 21, at 69 .

${ }^{24}$ Council Directive $2006 / 112 /$ EC of 28 November 2006 on the common system of value added tax.

${ }^{25}$ Eg Council Directive 2008/9/EC of 12 February 2008 laying down detailed rules for the refund of VAT, provided for in Directive 2006/112/EC, to taxable persons not established in the Member State of refund but established in another Member State.
} 
business-to-business supplies, where the supplier and customer are registered for VAT in an EU country, and business-to-consumer supplies, where only the supplier is registered. As a response to the challenges of the digital economy, a clearing house system established for a limited number of business-to-consumer digital supplies is expected to be expanded to eventually include all types of services and business-to-consumer sales of goods. ${ }^{26}$ Known as the 'one stop shop' system, the rules enable businesses to remit VAT on cross-border sales in the countries where they are registered and deal only with their local tax administration, which will then work through the clearing house to allocate taxes to the consumers' jurisdictions.

All the issues bilateral VAT treaties could address have been dealt with through the multilateral law and administrative agreements covering all EU member states. The VAT Directive eliminated jurisdictional conflicts for most cross-border trade by 23 of the 37 members of the OECD, an outcome with profound implications for the adoption of VAT treaties outside Europe.

\section{(ii) No VAT in the United States}

An important prompt for the global expansion of income tax treaty network was the shift in policy by the US, by far the world's most powerful economy, to move away from unilateral measures and negotiate bilateral treaties. ${ }^{27}$ As the world's only developed country without a VAT, the US suffered no similar jurisdictional conflicts with respect to this type of tax. Subordinate states levy retail sales tax, the main alternative to a VAT, but the federal government has neither constitutional authority nor political interest in negotiating with foreign governments on issues arising from possible overlaps or lacunae between state sales taxes and foreign VAT systems.

The absence of a national VAT in the US does not mean there should be disinterest in that country in collisions of legislative jurisdiction created by differing views on the place of consumption and questions of enforcement jurisdictions posed by the growth of digital platforms and supplies. To the extent that unilateral responses of VAT nations impact on US consumers importing from abroad or US businesses exporting their goods or services, the US federal government has a stake in solutions to crossborder VAT issues. That concern is clearly blunted, however, by the absence of any direct interest in VAT jurisdictional issues. As a result, the primary promotor of treaties as the optimal response to collisions of tax sovereignty claims in income tax plays no similar role in respect of VAT treaties. The shift to observer status only by the globe's most important economy undoubtedly delayed significantly the process of countries turning to treaties to solve cross-border VAT issues.

\section{(iii) Unilateral solutions}

In the absence of international agreements, states have resorted to unilateral responses to jurisdictional conflicts. Meanwhile, the OECD has been playing its leadership role in developing an internationally agreed framework of principles in the form of soft law guidance, with a view to facilitating consistent and coherent application of domestic rules to cross-border transactions. ${ }^{28}$

About 30 countries (most of which are OECD members) adopted unilateral relief of VAT incurred by foreign businesses on input purchases. ${ }^{29}$ However, in the countries where unilateral relief exists, the systems in place are largely inconsistent in terms of the mechanism used, the scope of VAT recovery and restrictions to refunds. Two main mechanisms are found to provide refunds to non-resident businesses. The first is a direct refund mechanism. Some countries provide direct refunds to non-resident businesses for VAT charged on business expenses incurred in their territories. The second is a

\footnotetext{
${ }^{26}$ European Commission, Proposal for a Council Implementation Regulation amending Implementing Regulation (EU) No 282/2011 as regards supplies of goods or services facilitated by electronic interfaces and the special schemes for taxable persons supplying services to non-taxable persons, making distance sales of goods and certain domestic supplies of goods, $\operatorname{COM}(2018) 821$ final.

${ }^{27}$ S Picciotto International Business Taxation (2013) p 39.

${ }^{28}$ A Charlet and S Buydens 'The OECD international VAT/GST guidelines: past and future developments' (2012) 1 World Journal of VAT/GST Law 175.

${ }^{29}$ OECD, above n 22, p 7.
} 
registration system used in countries where registration procedures are in place to allow foreign businesses that do not make taxable supplies in their territories to register and claim back input VAT.

Both mechanisms have weaknesses. Registration systems impose higher compliance burdens as non-resident businesses are required to register for VAT and file periodic returns. ${ }^{30}$ These costs may defer non-resident businesses from seeking a refund. Direct refund systems may be more susceptible to fraudulent refund claims because there is no easy way for the country in which expenditures were incurred to confirm the registration status of a business in another country. ${ }^{31}$ In addition, although countries provide relief through domestic laws on a unilateral basis, those using a direct refund mechanism tend to make the refunds conditional upon the grant of reciprocal refund rights by claimants' countries to their resident businesses. However, because reciprocity is addressed through domestic laws rather than mutual agreement, a registration system may not be recognised by countries using a direct refund scheme as providing similar benefits to their resident businesses. ${ }^{32}$

Some states, in particular developed countries, adopted unilateral measures to collect VAT on digital services and goods imported by domestic consumers, in both cases placing the responsibility for collecting the tax on foreign suppliers. ${ }^{33}$ The rules normally require foreign suppliers to register and pay VAT on supplies made to domestic consumers. The unilateral rules do not overcome the territorial limitations of enforcement jurisdiction of the state that has the jurisdiction to tax. Compliance with the rules by foreign businesses is voluntary because the customer's jurisdiction cannot audit, or sanction in the case of non-compliance, suppliers who do not have a physical presence in the territory. ${ }^{34}$ The rules have proved effective in respect of high-profile suppliers that take up a considerable market share for reputation reasons but have had little impact on small non-resident suppliers. ${ }^{35} \mathrm{~A}$ further reason for non-compliance by small suppliers is that the costs for complying with different sets of tax rules are very high, in particular if they have customers in many countries and have to keep up with changes in tax law in different countries and file foreign tax returns in foreign languages. The Australian government, for example, acknowledged that the unilateral measure 'has limitations and carries significant uncertainty about levels of compliance'. ${ }^{36}$ It nevertheless considered the approach to be the 'best available collection model' for adoption at the current stage. ${ }^{37}$

While unilateral measures have achieved some success as stop-gap measures, they fall well short of effective long-term solutions to the enforcement difficulties. Responses to legislative jurisdictional overlaps have not gone any further from general principles and soft law guidelines developed by the OECD. Nevertheless, the OECD is aware that guidelines and a common understanding of principles are not sufficient in resolving jurisdictional conflicts, given that countries inevitably interpret concepts differently, and a dispute resolution mechanism would be necessary. ${ }^{38}$ International cooperation by way of treaties appears to be a rational solution to the VAT jurisdictional problems.

Importantly, the reasons that explain the absence of VAT treaties do not undermine the necessity and desirability of such treaties. The absence of VAT treaties so far may be a result of the fact that VAT is a relatively new tax compared to income tax. The shift to a modern broad-based taxation on income

\footnotetext{
${ }^{30} \mathrm{P}$ Dunne GST: Business-to-Business Neutrality Across Borders - A Government Discussion Document about GST on Cross-Border Supplies between Businesses (Policy Advice Division of Inland Revenue, 2011).

${ }^{31}$ Ibid.

${ }^{32} \mathrm{Eg}$ a number of EU countries, including Italy and Spain, do not recognise that Australia provides refund entitlements to their registered businesses via a registration system.

${ }^{33} \mathrm{Eg}$ the EU, South Africa, Korea, Japan, New Zealand and Australia introduced domestic rules to cover collect VAT on supplies of digital services by foreign suppliers. Australia, New Zealand and the EU extended the rules to low-value goods supplied by foreign businesses.

${ }^{34}$ Addressing the Tax Challenges of the Digital Economy, Action 1 - 2015 Final Report, OECD/ G20 Base Erosion and Profit Shifting Project (OECD, 2015).

${ }^{35}$ Ibid, p 122.

${ }^{36}$ Productivity Commission, Australian Government, above n 20, p 10.

${ }^{37}$ Productivity Commission, Australian Government, above n 20, pp 4 and 26.

${ }^{38}$ The need for model-based VAT treaties was recognised in OECD 'The application of consumption taxes to the trade in international services and intangibles' (2004).
} 
was a key element in the transition from warfare states to modern welfare states in the early twentieth century in the industrialised world. ${ }^{39}$ The global spread of income tax preceded that of VAT by over 50 years. The regional and unilateral solutions may have retarded the adoption of VAT treaties, but the necessity of international cooperation will soon be learnt by individual states struggling with the challenges created by the rapid growth of the digital economy.

The path to cooperation might be accelerated by two recent events that have a dramatic impact on the global economy. The first is the outbreak of Covid-19 that is fundamentally changing the structure of the economy towards a more digitalised economy. The second is the UK's exit from the EU. Post-Brexit, the UK can no longer benefit from the EU solutions to VAT cross-border issues. Businesses are already seeing the disruptions caused by Brexit to UK-EU trade. Because of the new UK rules requiring EU businesses making supplies to UK customers to register for VAT in the UK, ${ }^{40}$ many EU exporters, in particular small businesses, ceased to supply to UK customers to avoid the complexities of UK VAT registration. ${ }^{41}$ Brexit offers a striking example of the impact of trade barriers created by the unilateral measure introduced by the UK, following the collapse of cooperation with EU countries. Nevertheless, the double shocks of Brexit and Covid-19 provide the UK with an opportunity to seek cooperation with the EU by way of treaty that may have wider international implications.

\section{Are income tax treaties a good model for a VAT treaty?}

In income tax, treaties have a long history of being used to resolve jurisdictional overlaps and conflicts. The well-established income tax treaty network is considered a solid basis for the adoption of VAT treaties. ${ }^{42}$ A key question is whether income tax treaties are a good model for a VAT treaty. This depends on the extent to which the jurisdictional problems in income tax and VAT are similar so that the income tax model can be directly applied to a VAT treaty and, where the underlying problems differ, whether the income tax model offers a solution to the VAT problems.

\section{(a) Overlapping legislative jurisdictions}

In an international setting, countries claim jurisdiction to tax income on the basis of two universally recognised and widely applied principles: the source principle and the residence principle. Under the source principle, a country applies the tax to income arising within its geographical borders. The principal ground advanced for source taxation is that resident and non-resident investors who benefit equally from the government should contribute equally to the cost of government. Generally, income tax laws require residents to contribute to national revenue by way of a tax imposed on their ability-to-pay measured by reference to their total worldwide income, without regard to its source. The two principles form the legitimate basis of a state's jurisdiction to tax income, deriving from different views on equity among individual taxpayers. ${ }^{43}$ Most countries' income tax is structured on the basis of a combination of the two principles and, as a consequence, residents are taxed on their worldwide income and non-residents are taxed on their domestic-sourced income.

Jurisdiction to tax based on both principles is entirely consistent with the territorial notion of sovereignty under international law, with the existence of a valid nexus (persons or the source of the income) within the territory. ${ }^{44}$ Concurrent application of the principles that establish sufficient

\footnotetext{
${ }^{39}$ S Picciotto 'Fragmented states and international rules of law' (1997) 6 Social \& Legal Studies 259.

${ }^{40} \mathrm{HMRC}$ 'Changes to VAT treatment of overseas goods sold to customers from 1 January 2021' ( 3 December 2020), available at https://www.gov.uk/government/publications/changes-to-vat-treatment-of-overseas-goods-sold-to-customers-from-1january-2021/changes-to-vat-treatment-of-overseas-goods-sold-to-customers-from-1-january-2021.

${ }^{41} \mathrm{R}$ Plummer 'EU firms refuse UK deliveries over Brexit tax changes' (BBC News, 4 January 2021), available at https:// www.bbc.co.uk/news/business-55530721.

${ }^{42}$ Eriksen, above n 3, at 169.

${ }^{43} \mathrm{NH}$ Kaufman 'Fairness and the taxation of international income' (1998) 29 Law \& Policy in International Business 145.

${ }^{44}$ Picciotto, above n 27, p 308.
} 
connection between the state exercising the tax jurisdiction and the taxpayer or taxable income can still produce extensive jurisdictional overlaps, which may arise in three circumstances: first, income earned by a resident of one jurisdiction from a source in another is subject to two competing tax claims (one country claims tax jurisdiction on the basis of source, while the other claims tax jurisdiction on the basis of residence); secondly, two countries claim an income is sourced in their territories (two countries claim tax jurisdiction on the basis of source); thirdly, two countries consider a person is resident in their territory (two countries claim tax jurisdiction on the basis of residence).

Without a deliberate relief system, overlapping jurisdictional claims will inevitably result in double taxation of the same income, placing businesses investing abroad at a competitive disadvantage. The double taxation problem has long been considered a barrier to international trade and investment.

The first type of jurisdictional overlap was the primary cause of double taxation that needed remedies. There are two possible responses to the problem - unilaterally forging sovereign taxing rights, or negotiating a split of tax jurisdiction between states with competing tax claims through cooperation. The initial response was negotiation of bilateral international agreements between neighbouring countries with close economic and political ties. ${ }^{45}$ The first income tax treaties comprise six treaties initiated by German federal states within the German Empire and one by the Empire itself in the period 1899 to $1912 .{ }^{46}$ Under domestic pressure from the business community, a few countries turned to unilateral responses, as an alternative to the slow process of bilateral negotiations, to overlapping tax claims. To promote outbound investment that was considered important for post-war economic recovery, the US in 1918 effectively opted to cede its taxing rights over residents where income derived by residents was subject to source country taxation abroad, by providing full credit against US tax liability for any taxes paid by US investors in a source country. ${ }^{47}$ Under the unilateral system, the source jurisdiction has the primary right to tax the income, whereas the residence country is left with only a residual taxing right where its tax rate is higher than that in the source country.

The spread of income tax systems and the liberalisation of trade and investment following World War I prompted broader international recognition of the double tax problem and only months after it was formed, the League of Nations was asked by the International Chamber of Commerce to develop a treaty-based solution to overlapping tax claims. ${ }^{48}$ Although the early ambition was to develop a comprehensive multilateral treaty, ${ }^{49}$ the League of Nations quickly realised that a multilateral agreement was not possible due to the great diversity of income tax systems and disagreement between countries over the division of tax jurisdiction. The result was the publication of several model treaties from the 1920s to 1940s for bilateral negotiations.

The treaties distinguished between different types of income and divided tax jurisdiction between two countries with tax claims based on source (source country) and residence (residence country) by applying one of three rules to each type of income, either restricting the source country's tax jurisdiction by setting a maximum tax rate on the particular type of income, providing the residence country with exclusive tax jurisdiction, or providing the source country with primary tax jurisdiction to leave the residence country with residual taxing space only.

The treaty models published between the 1920s and 1940s form the basis for the model treaty published by the OECD in 1963 and most recently updated in $2017,{ }^{50}$ which became the most influential model and is used as the basis for negotiations of almost all bilateral income tax treaties.

\footnotetext{
${ }^{45}$ See S Jogarajan 'Prelude to the international tax treaty network: 1815-1914 early tax treaties and the conditions for action' (2011) 31 OJLS 679.

${ }^{46} \mathrm{P}$ Schmidt 'The emergence of Denmark's tax treaty network - a historical view' (2018) 1 Nordic Tax Journal 49 at 50.

${ }^{47} \mathrm{R}$ Avi-Yonah 'Who invented the single tax principle?: an essay on the history of US treaty policy' (2014-15) 59 New York Law School Law Review 309 at 313.

${ }^{48} \mathrm{~K}$ Vogel 'Double tax treaties and their interpretation' (1986) 4(1) International Tax and Business Lawyer 4 at 10-11.

${ }^{49}$ 'Report of the Committee on International Double Taxation' (1946) Proceedings of the Section of International and Comparative Law 40.

${ }^{50}$ OECD Model Tax Convention on Income and on Capital (2017).
} 
While income tax treaties divide tax jurisdiction on the basis of source and residence, the definition of source and residence is a matter left to domestic laws. In a treaty, countries agree not to exercise fully their sovereign rights to apply worldwide income taxation of residents and source taxation of non-residents. Treaties restrain countries from applying domestic rules, without changing those rules in any way. This is justified by the need to preserve national fiscal sovereignty by interfering least with national tax rules. However, as noted, jurisdictional overlap will arise when two countries claim to be the source country of the same income or when a taxpayer is considered a resident of two countries based on domestic rules.

Traditionally treaties solved the 'dual residency' conflicts with a 'tie-breaker' rule, making the person a resident of only one of the two countries for the purposes of the treaty. ${ }^{51}$ Treaties contain no provision to directly address the problem of overlapping source claims but do provide a dispute resolution mechanism through a 'mutual agreement procedure' between 'competent authorities', the treaty term for divisions of national revenue agencies responsible for international tax conflicts. ${ }^{52}$

Prior to 2008 the OECD model contained no mechanism for resolving disputes where the two competent authorities were unable to reach agreement under a mutual agreement procedure, exposing taxpayers to the risk of double taxation. In one often-cited case, US authorities assessed the income derived by a German orchestra conductor as labour income with a source in the US while German authorities viewed the payments he received as royalty income sourced in Germany. ${ }^{53}$ The income was subject to full double taxation as both countries saw the income as sourced in their respective jurisdiction and the competent authorities were unable to reach an agreement under the mutual agreement procedure. ${ }^{54}$ The OECD model now provides for mandatory arbitration where authorities cannot reach agreement.

The legislative jurisdiction problems in VAT are not equivalent to those in income tax. ${ }^{55}$ In VAT, conflicts do not arise as a result of competing sovereign claims based on different principles because only one principle, the destination principle, determines the allocation of tax jurisdiction. The main type of jurisdictional overlap in income tax that promoted the adoption of income tax treaties does not arise in VAT. Nevertheless, the income tax treaty solution to this type of conflict has significant distributional implications for the adoption of VAT treaties, as will be discussed below in Section 3 .

The legislative jurisdiction conflicts in VAT mirror the other two types of conflicts in income tax. In income tax, both countries agree on the allocation of tax jurisdiction based on source and residence but have different views on the source of an income or the residence of a person. In VAT, states agree that tax jurisdiction is allocated to the country of consumption but have different rules to determine the place of consumption. The income tax treaty experience suggests that cooperation by way of treaty is possible only if treaties interfere with domestic rules in the least possible manner. The only treaty that harmonised place of taxation rules in VAT is the Treaty of Rome that authorises the Council to issue directives with which domestic laws must conform. Therefore, a common set of place of taxation rules arguably cannot be achieved by a treaty unless states agree to transfer part of their sovereignty to a transnational body, as is the case with the EU. ${ }^{56}$

However, it is not impossible to overcome the problems of incompatible concepts or definitions in national laws by way of treaty. The dispute resolution procedure in income tax treaties to be used when an individual or a company is defined to be a resident of the state in the national laws of two treaty partners is an example of how treaties can resolve conflicts of this sort. The income tax treaty provision is built on an understanding that both countries have different definitions of residency and requires

\footnotetext{
${ }^{51}$ Ibid, Art 4.

${ }^{52} \mathrm{OECD}$, above $\mathrm{n} 50$, Art 25. It is worth noting that direct taxpayer participation is limited in the mutual agreement procedure that aims to resolve disputes between the contracting states.

${ }^{53}$ Boulez v Commissioner, 83 TC 584 (1984).

${ }^{54}$ E Farah 'Mandatory arbitration of international tax disputes: a solution in search of a problem' (2009) 9 Florida Tax Review 703.

${ }^{55} \mathrm{G}$ Cooper and R Vann 'Implementing the goods and services tax' (1999) 21 Sydney Law Review 337, n 257.

${ }^{56}$ Ecker proposed a VAT model treaty that harmonises domestic place of taxation rules in Ecker, above $\mathrm{n} 3$.
} 
both to reconsider their domestic definition in light of higher level indicators. A similar approach could be used to resolve conflicts over the place of consumption. A VAT treaty would set out the place of consumption as the principle for allocating jurisdiction between treaty partners, an approach already adopted by most countries in their domestic laws, and fall back to dispute resolution procedures in cases of conflicts and inconsistencies.

\section{(b) Territorial constraints on enforcement jurisdiction}

While globalisation facilitates the growth of multinational enterprises and the mobility of capital, it also increases the chances for international tax avoidance and evasion, creating significant challenges for national tax administrations. In income tax, two enforcement issues arise from the mutual recognition of the other state's jurisdiction to tax income based on source and residence and the territorial constraints on enforcement jurisdiction: collection of information necessary to levy the tax and collection of tax debts in the other state's territory.

\section{(i) Information exchange}

To exercise its enforcement jurisdiction over residents, a state must have information about those taxpayers' domestic and foreign source income. Using tax procedure rules enacted pursuant to a state's legislative jurisdiction over resident entities and institutions, revenue authorities can collect information on taxpayers' income derived from domestic financial institutions, companies, trusts, employers, and so on. But the legislative and consequent enforcement jurisdictions apply only as far as the state's borders; without cooperation from source country authorities, it is difficult for a state to collect information about income derived by residents from foreign payers.

One jurisdiction, the US, has acted unilaterally to require a select group of income providers, foreign banks, to provide information on all US account holders but to date no other country has attempted unilateral action and the US has limited its information provision to information on foreign bank accounts. ${ }^{57}$ Critics of the law have claimed it is an unprecedented exercise of extraterritorial jurisdiction. ${ }^{58}$ Enforcement is wholly domestic, however, based on a $30 \%$ withholding of US source income paid to financial institutions that do not comply with reporting requirements, and in this way it could be argued the reporting system is a voluntary programme with implied consent by any foreign financial institution that wishes to derive income from the US. Nevertheless, given the importance of US transactions to foreign banks, the rule has de facto global application. It is unlikely that any other jurisdiction would be in a position to enforce unilateral rules of this sort.

The unique nature of the US unilateral enforcement rule limited to income derived through foreign bank accounts reveals the difficulty faced by residence countries seeking to unilaterally obtain the information necessary for imposing tax on the worldwide income of residents. Income tax treaties offer solutions to the enforcement difficulty by providing for information exchange between states by mutual agreement. ${ }^{59}$

The information exchange procedure can be used to address the inefficiency of one of the unilateral approaches to the legislative conflict in VAT that might arise when businesses incur costs in foreign jurisdictions. The direct refund system can be easily implemented in a treaty where both countries agree to treat the foreign tax (the tax ultimately collected by the country of consumption) as domestic tax and refund the tax on business acquisitions. A treaty could therefore provide double tax relief while overcoming the problem of inconsistent recognition of reciprocal treatment under the unilateral

\footnotetext{
${ }^{57}$ [US] Internal Revenue Code $\$ 1471-1474$, inserted by the Hiring Incentives to Restore Employment Act 2010. The measures are commonly referred to as the Foreign Account Tax Compliance Act (FATCA), though technically this Act never existed, with the provisions of the original Bill having been incorporated into other legislation.

${ }^{58}$ SD Michel and HD Rosenbloom 'FATCA and foreign bank accounts: has the US overreached?' (2011) Tax Analysts 709; R Seer 'Overview of legislation practices regarding exchange of information between national tax administrations in tax matters' (European Parliament, 2015).

${ }^{59}$ OECD, above n 50, Art 26.
} 
approaches. However, the implementation of the direct refund system in a treaty would only be effective if information exchange provision were in place, under which the business customer's country confirms the customer's registration status to minimise opportunities for fraudulent refund claims in the other country.

\section{(ii) Assistance in the collection of taxes}

A second aspect of enforcement jurisdiction in income tax is the collection of taxes once information has been collected, legislative jurisdiction exercised, and an assessment issued against the taxpayer. Taxes imposed on non-residents deriving local source income can be collected by way of withholding tax obligations imposed on the local persons paying the income. Collection of tax from residents is also relatively straightforward in most cases: inherent in the concept of residency is presence in the jurisdiction. There are instances, however, when taxation of residents is problematic, particularly if the resident departs for another jurisdiction with all his or her assets. The jurisdiction in which the person was resident can continue the assessment process and probably obtain a judgment debt against the defaulting taxpayer but a foreign court will not entertain an action to have a taxation debt enforced, even where they would normally recognise judgment debts from another jurisdiction on the basis of general comity principles. ${ }^{60}$

Foreign jurisdiction assistance with the collection of taxes is only possible if the foreign jurisdiction is required by binding legal agreements to provide the assistance. Since 2003, the OECD model treaty has included provision for mutual obligation of signatories to assist with the collection of each other's tax debts. Although provision of mutual assistance by treaty overcomes the formal international law constraints, not all jurisdictions agree to the inclusion of the measure in their treaties due to practical obstacles. For example, the great disparities with respect to substantive and procedural laws between countries may undermine the trust needed between the states to allow for enforcement measures based on another state's internal laws. ${ }^{61}$ However, while the mutual assistance provision in the OECD model is relatively new, it is expected that it will gain importance as requests for recovery assistance grow with the increased mobility of persons and capital. ${ }^{62}$

The enforcement difficulties concerning the collection of taxes differ in income tax and VAT. In income tax, neither the source nor residence country have significant difficulty with the collection of taxes. Mutual assistance in the collection of taxes is only provided on request after the requesting state conducts an audit and assesses the tax debts against a taxpayer. In contrast, the main enforcement difficulty in VAT is the collection of taxes from cross-border business-to-customer sales. A solution to the VAT problem could be an extension of the scope of mutual assistance in collection in income tax to cover ordinary VAT liabilities in cross-border sales. In fact, the EU has adopted this approach to address the problem partially internally, which can be used as the basis for developing VAT treaties.

A VAT treaty would mirror the one-stop-shop arrangements currently in place in the EU for certain intra-Community supplies of electronic services. The treaty would place the obligation for collecting VAT on business-to-consumer sales of digital supplies and low-value goods on the exporting country. The VAT would be collected at the rate applicable in the customer's jurisdiction by the exporting country as if it were its own tax. The exporting country would then transfer the revenue to the importing country via a clearing house mechanism. The revenue inflows and outflows would be netted against each other and only the net balance is transferred between each pair of countries. This arrangement is entirely consistent with the destination principle. The treaty, therefore, does not change the allocation of taxing rights between countries in any way. Apart from addressing the enforcement difficulty in importing countries, the treaty arrangement has the advantage of reducing the compliance costs for exporters, by removing the requirement for them to register and file tax returns in every

\footnotetext{
${ }^{60}$ The rule of non-enforcement of foreign tax claims, known as the 'revenue rule', is a well-established common law doctrine deriving from the UK. See L Robertson Jr 'Extraterritorial enforcement of tax obligations' (1966) 7(2) Arizona Law Review 219.

${ }^{61} \mathrm{P}$ Baker et al 'International assistance in the collection of taxes' (2011) Bulletin for International Taxation 281.

${ }^{62}$ Ibid, at 287.
} 
country where they have customers, that would otherwise arise under the unilateral measures. This would reduce the tax barriers to cross-border trade, in particular for small businesses, created by the unilateral measures.

The proposed model requires closer cooperation in terms of mutual assistance than in the income tax treaties. The income tax provision aims to establish a mechanism for states to lend assistance in recovering unpaid taxes in other states upon request. The proposed VAT treaty would make it automatically obligatory for states to collect the current tax applied to certain supplies by other countries. The practical difficulties encountered in income tax should be less significant in VAT, because the structure and principles of the VAT systems around the globe are much more similar. An obstacle to the proposed cooperative regime could be that countries, in particular developed countries equipped with strong tax administrations, may be reluctant to rely on foreign tax administrations for the collection of their own taxes due to the disparities in administrative capacities. However, current unilateral measures that rely on foreign business suppliers for the collection of VAT could be far less effective than the collection by even weak tax administrations.

Any progress that could be made within the EU on its one-stop-shop mechanism would contribute to the political acceptance of the proposed treaty model, given that 27 member states would have already agreed on the treaty terms and would negotiate with non-EU countries as a single bloc. The EU has recognised the necessity of seeking international administrative cooperation in ensuring the effectiveness of its VAT laws. In 2018, it signed an agreement with Norway to strengthen administrative cooperation in preventing VAT fraud and assisting each other in the recovery of VAT claims. ${ }^{63}$ As part of its action plan to support the Covid-19 recovery strategy, the European Commission will propose negotiations of administrative cooperation agreements, similar to the agreement with Norway, with other main EU trade partners. ${ }^{64}$ The EU initiatives clearly show the political willingness to enhance international VAT cooperation and will open the door to further cooperation in the form of the treaty model outlined in this paper.

\section{Distributional consequences}

As in many other areas of cooperation, although it is in the interest of all countries to cooperate, the benefits of international tax cooperation are more often than not distributed unevenly between states. With the pandemic highlighting the necessity and urgency of providing assistance to developing countries through international cooperation, the distributional consequences should be an important consideration in determining the desirability of cooperation in the post-Covid era. In addition, the distributional consequences to a large extent determine whether treaties take the form of bilateralism or multilateralism. The income tax treaty experience offers important lessons for VAT treaties as regards distributional consequences.

\section{(a) Income tax treaties}

The distributional consequences of income tax treaties primarily derive from the functions the treaties perform in resolving one type of legislative jurisdictional overlap. In this respect, income tax treaties present two distinct but intertwined features. First, the main function of income tax treaties is to directly regulate the distribution of legislative jurisdiction. In other areas of economic regulation, treaties may affect states' legislative jurisdiction but treaty law does not generally govern the jurisdiction in the way that tax treaties do. ${ }^{65}$ Secondly, income tax treaties are bilaterally negotiated between each pair of

\footnotetext{
${ }^{63}$ Agreement between the European Union and the Kingdom of Norway on administrative cooperation, combating fraud and recovery of claims in the field of value added tax (2017).

${ }^{64}$ Commission 'An action plan for fair and simple taxation supporting the recovery strategy' (Communication) COM (2020) 312 final.

${ }^{65}$ Ryngaert noted the 'near total absence of useful treaty law in the field of jurisdiction' in C Ryngaet Jurisdiction in International Law (Oxford: Oxford University Press, $2^{\text {nd }}$ edn, 2015) p 4.
} 
countries. However, almost all the bilateral income tax treaties follow the pattern of the OECD model and define the limits of tax jurisdiction in a largely uniform manner. ${ }^{66}$

\section{(i) Distributional consequences}

The primary objective of income tax treaties is to eliminate double taxation caused by overlapping jurisdictional claims by two countries based on source and residence. This objective is achieved by dividing tax jurisdiction between the two countries in treaties to establish exclusive rather than concurrent taxing rights. However, treaties allocate more taxing rights to residence countries than to source countries on a reciprocal basis. The OECD model gives the residence country the exclusive right to tax royalties, as well as business income unless the income is earned through a permanent establishment in the source country. In addition, residence countries are given the primary right to tax dividends and interest.

A state can be a source country in one transaction and a residence country in another. If capital flows between two countries are more or less equal in both directions, the two countries have roughly equal chances to be source or residence countries. The allocation bias towards residence taxation does not have apparent distributional consequences. However, if capital flows are primarily one way, as is often the case between a developed country and a developing country, the developing, capital-importing, country is almost invariably the source country. The unequal distribution of tax jurisdiction in treaties may not be a problem in itself. It only becomes a problem if the distributional effects give rise to unfairness. There seems to be an assumption that a flow of benefits from poor countries to rich countries is unfair. The question of fairness in cooperation, however, largely depends on the fairness of arrangements without cooperation.

There is nevertheless a lack of consensus on the fair division of tax jurisdiction over international income between countries, and developing countries and developed countries will inevitably have different views on fairness. ${ }^{67}$ The difficulty has no doubt been compounded by the fact that a state's tax jurisdiction based on both source and residence is accepted as legitimate by other countries. If redistribution is not an objective of international tax systems, the baseline for assessing fairness is that all countries have equal right to impose tax on the basis of source and residence. ${ }^{68}$ Evaluated against this baseline, tax treaties create an allocation bias that leads to unfair distribution of tax jurisdiction in favour of developed countries, more seriously restricting the ability of poorer countries to develop their national tax policy to raise the desired revenue.

Indeed, the OECD acknowledged in its 1963 model the bias towards residence over source countries and suggested that for this reason the model should be used only as the basis for treaties between OECD nations, that is, developed economies. ${ }^{69}$ The caution had a short-lived impact as developed countries sought to expand their treaty networks to less developed economies receiving investment funds from residents in the developed nations and used the OECD model as the basis for negotiations. Concern by developing economies led the United Nations (UN), the successor of the League of Nations, to reengage with the model treaty process in 1967 and in 1979 the UN published a manual on negotiating tax treaties between developed and developing countries, followed in 1980 by an alternative model tax treaty with a more balanced division of taxing rights towards source countries. ${ }^{70}$ However, the UN had the OECD model as its starting point and the allocation principles, structure and language used in the UN model closely resemble those in the

\footnotetext{
${ }^{66}$ This point was made in 1964 when there were only 500 income tax treaties. See Mann, above n 17, at 109.

${ }^{67} \mathrm{~K}$ Brooks 'Inter-nation equity: the development of an important but underappreciated international tax policy objective' in JG Head and R Krever (eds) Tax Reform in the 21 $1^{\text {st }}$ Century (Kluwer Law International, 2009); and M Devereux et al Taxing Profits in a Global Economy (Oxford: Oxford University Press, 2021) p 39.

${ }^{68}$ Whether redistribution should have a role to play in international tax arrangements is a question that has been asked but has yet to be answered. See 'The role of tax treaties in the $21^{\text {st }}$ century' (2002) Bulletin for International Taxation.

${ }^{69}$ OECD Draft Double Taxation Convention on Income and Capital (1963).

${ }^{70} \mathrm{UN}$ United Nations Model Double Taxation Convention between Developed and Developing Countries (1980).
} 
OECD model. ${ }^{71}$ The intervention of the UN with the alternative model mitigated, but did not remove, the bias towards residence countries which resulted from the basic structure of bilateral treaties that remove or limit the tax jurisdiction of source countries. Moreover, empirical studies suggest that the actual inclusion of UN provisions in treaties signed by developing countries has not been very successful. ${ }^{72}$

The unfair distribution of tax jurisdiction will likely result in an unfair distribution of tax revenue, creating 'anomaly of aid in reverse - from poor to rich countries'. ${ }^{73}$ But this is not necessarily the case, as the revenue gain or loss depends not only on the restrictions on taxing rights, but also on the changes of capital inflows and outflows as a result of the treaty, among other factors. ${ }^{74}$

The necessity of tax treaties has increasingly been challenged on the ground of the distributional consequences. ${ }^{75}$ It is often argued that both unilateral and bilateral approaches resolve the jurisdictional overlaps by dividing the tax jurisdiction between source and residence countries and the main difference between the two approaches is distributional consequences, with the unilateral approach favouring source countries and the bilateral approach favouring residence countries. ${ }^{76}$ Concerns over the distributional consequences have prompted tax scholars and international organisations to advise developing countries to be cautious about entering into treaty negotiations with developed countries. ${ }^{77}$ In fact, most developed countries have adopted the unilateral approach in their domestic laws that gives source countries the primary taxing rights. From a bargaining perspective, developing countries would lose taxing rights even if tax treaties divided tax jurisdiction equally between source and residence countries. The unfair distributional consequences make it more difficult to justify the desirability of income tax treaties, especially if the main objective of treaties can be achieved unilaterally.

\section{(ii) Bilateralism or multilateralism?}

The distributional consequences are a main factor that determines whether tax treaties are bilateral or multilateral. Multilateral agreements in other areas of law are not uncommon, in particular trade policy that is also a key area of a country's economic interest. ${ }^{78}$ In the field of taxation, multilateral treaties are often developed in the issue areas concerning enforcement jurisdiction. An example is the Convention on Mutual Assistance in Tax Matters. However, income tax treaties are historically bilateral.

The first multilateral income tax treaty was concluded in 2017 as part of a global project initiated by the G20 and the OECD that aims to set up an international framework to address base erosion and profit shifting (BEPS) strategies by multinationals. ${ }^{79}$ The multilateral treaty is an important instrument to streamline the implementation of treaty-related BEPS measures. Its effect is simultaneous renegotiation of thousands of bilateral tax treaties while preserving the bilateral nature of tax treaties. The success of the multilateral treaty has to be viewed with two caveats. First, the primary objective of the multilateral treaty is to address treaty-related tax avoidance and evasion. Unlike bilateral treaties,

\footnotetext{
${ }^{71}$ The differences between the OECD and UN Models are discussed in DR Whittaker 'An examination of the OECD and UN model tax treaties: history, provisions and application to US foreign policy' (1982) 8 North Carolina Journal of International Law and Commercial Regulation 39.

${ }^{72} \mathrm{~W}$ Wijnen and J de Goede 'The UN model in practice 1997-2013' (2004) Bulletin for International Taxation 118; V Daurer and R Krever 'Choosing between the UN and OECD tax policy models: an African case study' (2014) 22 African Journal of International and Comparative Law 1.

${ }^{73} \mathrm{CR}$ Irish 'International double taxation agreements and income taxation at source' (1974) 23 ICLQ 292.

${ }^{74} \mathrm{EM}$ Zolt 'Tax treaties and developing countries' (2018) 72 Tax Law Review 111. Empirical studies show mixed results of the impact of tax treaties on foreign direct investment. For a summary of the empirical results see T Dagan International Tax Policy: Between Competition and Cooperation (Cambridge: Cambridge University Press, 2018) pp 107-110.

${ }^{75}$ See eg A Easson 'Do we still need tax treaties?' (2000) Tax Treaty Monitor 619.

${ }^{76} \mathrm{~K}$ Brooks and $\mathrm{R}$ Krever 'The troubling role of tax treaties' in V Thurinyi and G Michielse (eds) Tax Design Issues Worldwide (Kluwer Law International, 2015); Dagan, above n 74, p 104.

${ }^{77}$ IMF 'Spillovers in international corporate taxation' (2014).

${ }^{78} \mathrm{~A}$ notable example is the General Agreement on Tariffs and Trade.

${ }^{79}$ Multilateral Convention to Implement Tax Treaty Related Measures to Prevent Base Erosion and Profit Shifting.
} 
the multilateral treaty is not concerned with division of tax jurisdiction. Although some provisions in the multilateral treaty may slightly change the allocation of taxing rights between the two parties to a bilateral treaty, the change was the result of the need to address treaty abuse. ${ }^{80}$ Secondly, the multilateral treaty - by its very nature - operates on a bilateral basis. It modifies a bilateral treaty only to the extent that the two parties to the bilateral treaty choose to apply a provision in the multilateral treaty.

Bilateralism of tax treaties is a result of states jealously guarding their tax sovereignty. ${ }^{81}$ Although income tax treaties perform functions in respect of both legislative and enforcement jurisdictions, treaty responses to enforcement issues, such as information exchange and assistance in the collection of tax debts, are relatively distributionally neutral and are therefore less contentious. In terms of legislative jurisdiction, however, the distributional bias in tax treaties can hardly win the international consensus necessary for a multilateral treaty. Experience with bilateral income tax treaties and multilateral administrative cooperation treaties suggests that it is the concern over distributional consequences resulting from an allocation of legislative jurisdiction that makes a multilateral income tax treaty unachievable.

Another distinct feature of income tax treaties is that almost all the bilateral treaties follow the same principles of allocating tax jurisdiction enshrined in the OECD model. Although the initial purpose of the model was to serve as a manual that reduces transaction costs that would otherwise incur in bilateral negotiations, the model itself is a product of multilateral negotiation between OECD members. The model is well regarded as 'a template for a multilateral web of treaties', with its influence reaching far beyond the OECD countries. ${ }^{82}$

Income tax treaties thus contain elements of both bilateralism and multilateralism. ${ }^{83}$ While the key allocation principles were multilaterally negotiated by the OECD members and followed in virtually all treaties, modifications based on these principles suited to specific political and economic circumstances between each pair of treaty partners were negotiated bilaterally. Bilateralism is a manifestation of the fact that legislative jurisdiction to tax is a crucial element of sovereignty and bilateral treaties are a better instrument to preserve tax sovereignty. Pure bilateral negotiations, however, would inevitably lead to high transaction costs. The multilateral negotiation of key distributive principles provides a means to minimise the transaction costs. Bilateralism combined with a common model is therefore a middle ground that achieves the benefits of cooperation while preserving a degree of flexibility for differentiated negotiations with different treaty partners.

\section{(b) VAT treaties}

Two important questions that need to be considered for the adoption of a VAT treaty are its distributional consequences and whether bilateral treaties or a multilateral treaty would be the preferred option. Since the proposed VAT treaty requires closer enforcement cooperation, in particular in respect of assistance in the collection of taxes, than in the income tax treaties, it can be expected that the VAT treaty would not be distributionally neutral.

Similar to the distributional problems in bilateral income tax treaties, VAT treaties that assign rights and duties on a reciprocal basis would have unequal distributional consequences once trade flows and administrative capacities are taken into account. If outflows and inflows between two countries were roughly balanced, the two treaty partners would have similar incentives to collect the foreign tax. Any significant imbalance in flows between the two parties could lead to uneven distribution of obligations or administrative costs. ${ }^{84}$ Moreover, asymmetries in administrative capacities may have a more direct

\footnotetext{
${ }^{80} \mathrm{P}$ Baker 'BEPS and the principles of international taxation' (Tax Advisor, 7 September 2016).

${ }^{81}$ Arnold et al, above n 21, at 94 .

${ }^{82}$ JFA Jones 'The David R Tillinghast Lecture: are tax treaties necessary?' (1999) 53 Tax Law Review 1.

${ }^{83}$ T Rixen 'Bilateralism or multilateralism? The political economy of avoiding international double taxation' (2010) 16 European Journal of International Relations 589.

${ }^{84}$ The cost of collecting VAT in the UK, for example, was $0.7 \%$ of the revenue collected in $2010-11$. See HMRC 'Annual report and accounts 2010-11' https://assets.publishing.service.gov.uk/government/uploads/system/uploads/attachment_data/ file/89199/annual-report-accounts-1011.pdf.
} 
impact on revenue yields, with countries that have strong administrative capacity collecting a larger proportion of foreign VAT due. An important lesson of the income tax treaty experience is that where the distributional consequences of treaties are non-neutral, the international consensus needed for a multilateral treaty is more difficult to achieve. Therefore, a realistic starting point for international VAT cooperation would be the adoption of bilateral treaties.

Although the proposed VAT treaty would also lead to distributional bias, the distributional consequences are nevertheless desirable. Contrary to the direction of flow of benefits in income tax treaties, VAT treaties between developed and developing countries may attribute larger benefits to developing countries. The continued growth of consumer demand for cross-border business-to-consumer sales driven by rising incomes in the developing world creates new opportunities for e-commerce market players in developed countries. However, weaker administrative capacity in developing countries places constraints on their ability to capture cross-border sales. VAT treaties would enable developing countries to piggy-back off the administrative capacity of countries selling into their territories while increasing the competitiveness of their domestic exporters.

The benefits that would accrue to developing countries should be seen as a counterbalance to the unfair distributional consequences of income tax treaties. ${ }^{85}$ The VAT treaty provisions could be incorporated into the existing income tax treaties to improve the overall fairness of tax treaties, although the VAT treaty may not completely offset the negative distributional consequences of the income tax treaty. Building VAT treaties into income tax treaties would also strengthen developing countries' bargaining positions in negotiating VAT provisions, since they have already made greater compromises in the income tax treaties.

The income tax treaty experience shows that efficient bilateral negotiations should be accompanied by a model treaty to reduce transaction costs. The OECD is well-placed to develop the VAT treaty model given its leading role in formulating international tax rules and expertise in developing the income tax treaty model. Equally importantly, the proposed model could complement the OECD's current work on tax challenges arising from digitalisation. ${ }^{86}$

The development of VAT treaties could form part of the wider coordinated actions in response to the Covid-19 crisis. The pandemic has exposed inequalities and divisions within and between countries, and the pandemic itself is likely to further increase the existing disparities. Although almost all countries are severely affected by the pandemic, the economic impact of Covid-19 and the ability to respond to the crisis vary substantially across social groups and countries at different levels of development. Developing countries facing the challenges with weaker healthcare systems, limited resources and less flexibility for fiscal and monetary policy are being hit the worst and recovery is expected to take longer in these economies. International organisations have emphasised the importance of providing special support to developing countries in light of the interconnectedness and interdependence of territorial states revealed by the pandemic. ${ }^{87}$ In addition to direct financial support, it is also imperative for the international community to support tax capacity building in developing countries to assist with their long-term recovery. ${ }^{88}$ Addressing the common challenges in VAT, the most important source of revenue for most middle- and low-income countries, should be a priority on the international tax agenda as the pandemic continues to unfold. ${ }^{89}$ The proposed VAT treaty could be a first step towards building a fairer and more sustainable international tax system.

\footnotetext{
${ }^{85} \mathrm{~A}$ similar view was expressed in terms of enforcement cooperation in income tax. See Picciotto, above n 27 , p 305.

${ }^{86}$ See eg above n 34; Tax Challenges Arising from Digitalisation - Report on Pillar One Blueprint \& Report on Pillar Two Blueprint (OECD, 2020).

${ }^{87} \mathrm{OECD}$ 'Tax and fiscal policy in response to the coronavirus crisis: strengthening confidence and resilience' (19 May 2020).

${ }^{88} \mathrm{~V}$ Gaspar et al 'Facing the crisis: the role of tax in dealing with Covid-19' (Flatform for Collaboration on Tax, 16 June 2020), available at https://www.tax-platform.org/news/blogs/facing-crisis-role-tax-dealing-with-covid-19.

${ }^{89}$ The important role VAT will play for the Covid-19 recovery is highlighted by the European Commission in its recent initiative to reduce the VAT gap in the EU. See 'VAT - mind the VAT gap' (European Commission), available at https:// ec.europa.eu/info/law/better-regulation/have-your-say/initiatives/12816-Mind-the-VAT-Gap.
} 


\section{Conclusion}

Whilst the Covid-19 pandemic causes massive disruptions and presents unprecedented challenges on all fronts, it opens up a unique opportunity for the global community to address the existing tax challenges through international cooperation and move towards a more equitable international tax system for the benefit of all countries. The VAT treaties proposed in this paper could be the start of this process.

The challenges countries are facing in taxing cross-border transactions, in particular for digital supplies and low-value goods, under VAT become more prominent in light of the digital transmission accelerated by the pandemic. Treaties offer more effective solutions to over-taxation and undertaxation that might occur as a result of legislative jurisdiction overlaps and territorial constraints on enforcement jurisdiction. Legislative jurisdiction overlap might arise when two countries have inconsistent domestic rules on the place of consumption, or when businesses incurring foreign expenses are denied refunds in the foreign country. Enforcement jurisdiction may be subject to territorial constraints, and consequently, cannot be exercised effectively in the case of digital supplies and low-value goods imported by domestic consumers.

The current income tax treaties provide a good model for a VAT treaty, although the underlying jurisdictional issues in income tax and VAT are different. The inconsistent domestic rules on the place of consumption can be addressed through a dispute resolution mechanism. The treaty would establish a refund system for input VAT incurred by businesses registered in the other country, with an information exchange procedure in place to reduce the risk of fraudulent refund claims. The VAT treaty would require closer cooperation via mutual assistance in the collection of taxes modelled on the one-stop-shop mechanism currently used in the EU to overcome the enforcement difficulty in terms of cross-border business-to-consumer sales of goods and digital supplies. These treaty measures would ease under-taxation and over-taxation in cross-border transactions, removing tax obstacles for businesses and increasing revenue yields for governments. The VAT treaty measures outlined in this paper provide a basis for policymakers to commence their work in this area.

The pandemic made the case for fostering international cooperation in areas where assistance to developing countries can be provided. Taxation is a key area for support because of its vital role in supporting economic mobilisation and financing recovery. However, the distributional consequences arising from the existing income tax treaties are normatively unappealing, with developed countries reaping more benefits from cooperation. In contrast, the proposed VAT treaties that favour developing countries would lead to normatively attractive distributional consequences. Accordingly, one further compelling reason for the adoption of VAT treaties, in addition to the solution to the jurisdictional problems, is precisely to secure the attractive distributional consequences such treaties would produce. These attractive distributional consequences would be worth pursuing in their own right, and a fortiori as a corrective to the unappealing distributional consequences that the income tax treaties generate.

Revisiting the income tax experience reveals that where the distributional consequences are nonneutral, bilateral treaties are politically more attainable than a multilateral treaty. A model treaty is nevertheless needed to facilitate bilateral negotiations. Therefore, the proposed VAT treaty should follow the path of income tax treaties and take the form of bilateral treaties based on a common model. The potential political resistance from developed countries as a result of the distributional bias may be reduced by incorporating the VAT provisions into the existing income tax treaties. The need to raise revenue in all countries in the wake of the pandemic could provide new impetus for overcoming political hurdles and reaching agreements internationally.

Cite this article: Zu Y (2022). Developing VAT treaties: international tax cooperation in times of global recovery. Legal Studies 42, 159-177. https://doi.org/10.1017/lst.2021.37 